\title{
Bioaccumulation of organotin in relation to the life history of the brown trout Salmo trutta
}

\author{
Madoka Ohji ${ }^{1, *}$, Hiroya Harino ${ }^{2}$, Takaomi Arai ${ }^{3}$ \\ ${ }^{1}$ Institute of Symbiotic Science and Technology, Tokyo University of Agriculture and Technology, Fuchu, Tokyo 183-8509, Japan \\ ${ }^{2}$ School of Human Sciences, Kobe College, 4-1 Okadayama, Nishinomiya, Hyogo 662-8505, Japan \\ ${ }^{3}$ International Coastal Research Center, Ocean Research Institute, The University of Tokyo, 2-106-1 Akahama, Otsuchi, \\ Iwate 028-1102, Japan
}

\begin{abstract}
In order to examine the accumulation pattern of organotin compounds (OTs) in relation to the migration of diadromous fish, the concentrations of tributyltin (TBT) and triphenyltin (TPT) compounds and their derivatives were determined in the liver tissues of both sea-run (anadromous) and freshwater-resident (nonanadromous) types of the brown trout Salmo trutta. Ontogenic changes in the otolith strontium ( $\mathrm{Sr}$ ) and calcium (Ca) concentrations were examined along the life history transect to discriminate the migration types. The sea-run and freshwater-resident life history styles of $S$. trutta were found to coexist sympatrically based on the otolith Sr:Ca ratio. The otolith Sr:Ca ratio of sea-run $S$. trutta fluctuated strongly along the life history transect in accordance with the migration pattern between sea and freshwater. In contrast, the Sr:Ca ratios of freshwater-resident fish remained at constantly low levels throughout the otolith. There were generally no significant correlations between TBT and TPT accumulation and various biological characteristics such as total length (TL), body weight (BW) and sex. It is noteworthy that the TBT and TPT concentrations in sea-run $S$. trutta were significantly higher than in freshwater-resident individuals, although they are intraspecies. These results suggest that the sea-run $S$. trutta has a higher ecological risk of TBT and TPT exposure than the freshwater residents during their life history.
\end{abstract}

KEY WORDS: Tributyltin · Triphenyltin $\cdot$ Salmo trutta $\cdot$ Migration $\cdot$ Ecological risk

Resale or republication not permitted without written consent of the publisher

\section{INTRODUCTION}

In the past several decades, tributyltin (TBT) and triphenyltin (TPT), which are representative groups of organotin compounds (OTs), have been widely utilized as active biocides in marine antifouling paints applied to ship hulls to prevent the attachment and growth of marine organisms such as barnacles, mussels and algae (Snoeij et al. 1987, Blunden \& Evans 1989, Bosselmann 1996). TBT and TPT cause adverse effects on nontarget aquatic organisms (Fent \& Meier 1994, Ohji et al. 2002a,b, 2003a,b, Grzyb et al. 2003). Despite regulation of their use in antifouling paints, high concentrations of TBT and TPT are still being detected in the aquatic ecosystem (Harino et al. 2002, Ohji et al. 2007a). Recently, it was reported that TBT affects not only marine and freshwater fishes (Ward et al. 1981, Wester \& Canton 1987, Fent \& Meier 1992) but also diadromous fishes such as anadromous fish, the masu salmon Oncorhynchus masou, which has both sea-run and freshwater-resident migratory phases (Ohji et al. 2006a, $2007 b)$. These results suggest that the anadromous $O$. masou has a higher ecological risk of TBT exposure during its life history than freshwater-resident fish, although both types belong to the same species. Therefore, differences in TBT (as well as TPT) accumulation between migratory types of other anadromous fish might also be similar to that in $O$. masou. However, there have been few studies to date on the relationship between OT accumulation and migratory history in diadromous species (Ohji et al. 2006a,b, 2007b, 2009).

The brown trout Salmo trutta Linnaeus is an important domestic resource in its native range. It is an economically important game fish with a high conservation value (Elliott 1994, Watson 1999). The fish is highly polytypic, with individual fish within a population 
showing considerable variation in life history strategy (Elliott 1994). Two major life history pathways have been recognized in $S$. trutta: i.e. freshwater-resident brown trout and migratory sea trout (Elliott 1994, Watson 1999). The former reside in freshwater throughout their life, whereas the latter migrate to the sea to feed before returning to their natal streams to spawn. Many populations of $S$. trutta composed of both nonanadromous (freshwater-resident) and anadromous (sea-run) individuals coexist in the same freshwater environment and utilize the same freshwater spawning areas. The relative contributions of sea-run and freshwater-resident $S$. trutta to the adult spawning population and to egg deposition and juvenile production are of central importance to the development of effective management policies for stock conservation. Since TBT and TPT have primarily been used in marine environments, there may be differences in the accumulation of these compounds between the 2 migratory types of $S$. trutta.

Wavelength dispersive electron microprobe measurement of the strontium $(\mathrm{Sr})$ and calcium $(\mathrm{Ca})$ ratios in otoliths has recently been considered as a method for distinguishing between freshwater and marine migratory phases in diadromous fishes (Campana 1999, Arai et al. 1997, 2002). The Sr content in otoliths is higher in sea migrants than in freshwater residents, and $\mathrm{Sr}$ is known to alternate with $\mathrm{Ca}$ in bony tissues in proportion to the concentrations in the surrounding water. Furthermore, $\mathrm{Sr}$ is permanently incorporated in this way during growth, so that the difference in Sr between growth zones can be used to reconstruct the previous individual life history of diadromous species (Kalish 1990, Secor et al. 1995, Arai \& Tsukamoto 1998, Tsukamoto \& Arai 2001, Arai et al. 2002). Thus, the Sr:Ca ratios of otoliths allow us to determine whether or not individual brown trout actually move between different habitats with differing salinity regimes. This technique should aid in revealing minute OT accumulation patterns accompanying an individual fish's migratory history as well as in reconstructing its migratory history.

The present study aimed to examine differences in the accumulation patterns of butyltin compounds (BTs), including TBT and its derivatives, dibutyltin (DBT) and monobutyltin (MBT), and phenyltin compounds (PTs), including TPT and its derivatives, diphenyltin (DPT) and monophenyltin (MPT) in the livers of the 2 migration types of the brown trout Salmo trutta collected in sea and freshwater habitats in Japan, and to compare OT accumulation with life history. The environmental histories of $S$. trutta were reconstructed using ontogenic changes in the otolith Sr:Ca ratios along the life history transect. Results of the present study may provide valuable clues for understanding the ecological risk posed by OTs and the variations in their accumulation due to migration in anadromous fish.

\section{MATERIALS AND METHODS}

Fish collection. Salmo trutta were collected from Japanese sea and fresh waters by set nets or fishing in December 2006 to June 2007 (Table 1, Fig. 1). Collection sites were Hakodate Bay, located at Hokkaido Island (Fig. 1), and the adjacent Hekirichi and Kunebetsu Rivers ( $15-20 \mathrm{~km}$ from the bay), where there is no tidal influence and salinity is 0 . A total of 24 brown trout ( 6 males, 12 females, 6 unknown) were used (Table 1) and livers were dissected. All samples were stored in a freezer at $-20^{\circ} \mathrm{C}$ until chemical analysis. Fork length ( $\mathrm{FL}$, to the nearest $1 \mathrm{~mm}$ ) and body weight (BW, to $0.1 \mathrm{~g}$ ) were measured, and sex was determined by examining the gonads.

Chemical analysis of organotins. Concentrations of OTs in the biological samples were determined based on the method of Ohji et al. (2006a,b,c, 2007b, 2009) with some modifications. One gram of homogenated liver from each fish was placed in a centrifuge tube and $100 \mu \mathrm{l}$ of mixed acetone solution including $1 \mu \mathrm{g} \mathrm{ml}^{-1}$ each of tributyltin monochloride (TBTCl)- $\mathrm{d}_{27}$, dibutyltin dichloride (DBTCl)- $\mathrm{d}_{18}$, monobutyltin trichloride (MBTCl) $-d_{9}$, triphenyltin monochloride (TPTCl)- $d_{15}$, diphenyltin dichloride (DPTCl)- $\mathrm{d}_{10}$, and monophenyltin trichloride (MPTCl)- $\mathrm{d}_{5}$ was added to the centrifuge tube as a surrogate standard. The mixture was extracted with $10 \mathrm{ml}$ of $1 \mathrm{M} \mathrm{HCl}$-methanol/ethyl acetate (1/1) by shaking for $10 \mathrm{~min}$. After centrifugation for $10 \mathrm{~min}$, the residue was extracted and centrifuged again in the same

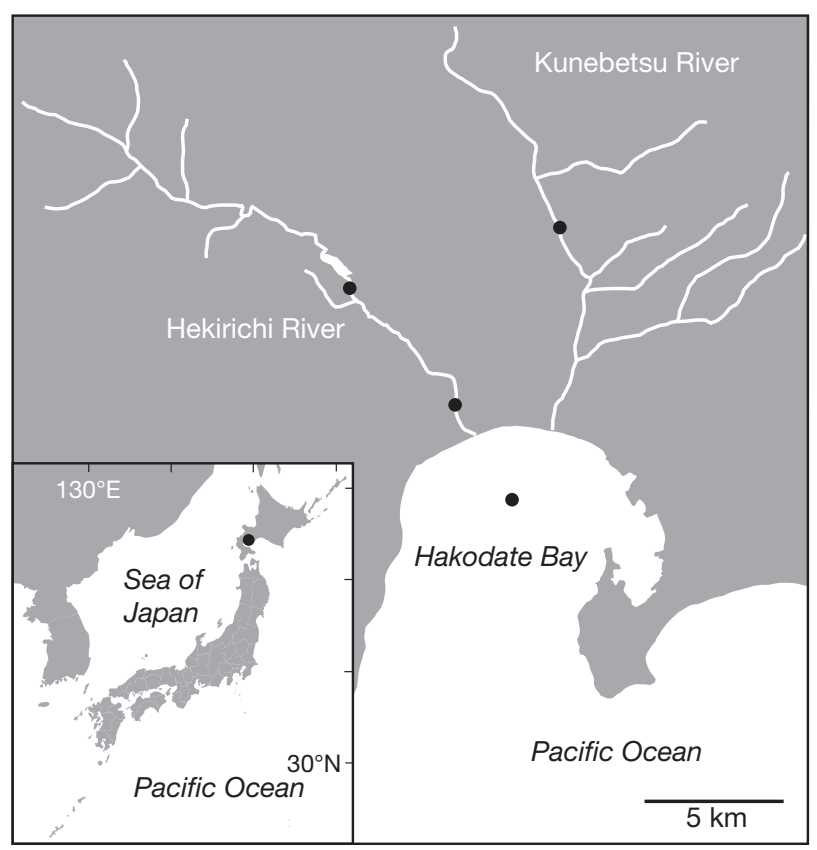

Fig. 1. Sampling sites $(\bullet)$ at the Hekirichi and Kunebetsu Rivers and Hakodate Bay, Japan. Sampling was conducted at 4 sites in Japanese waters 
Table 1. Salmo trutta. Specimens used for organotin and otolith microchemistry analyses. Specimens were collected from December 2006 to June 2007

\begin{tabular}{|c|c|c|c|c|c|c|c|c|}
\hline \multirow{2}{*}{$\begin{array}{l}\text { Migratory } \\
\text { history }\end{array}$} & \multirow[t]{2}{*}{ Number } & \multirow[t]{2}{*}{ Sex } & \multicolumn{2}{|c|}{ — Fork length $(\mathrm{mm})$} & \multicolumn{2}{|c|}{${ }_{-}$Body weight $(\mathrm{g})$} & \multicolumn{2}{|c|}{ Mean Sr:Ca $\times 1000$} \\
\hline & & & Mean $\pm \mathrm{SD}$ & Range & Mean \pm SD & Range & Mean $\pm \mathrm{SD}$ & Range \\
\hline Total & 24 & $\begin{array}{c}\text { Male } 6, \\
\text { female } 12, \\
\text { unknown } 6\end{array}$ & $346.2 \pm 112.4$ & $(174.0-564.0)$ & $708.8 \pm 584.3$ & $(65.0-2552.0)$ & $1.5 \pm 0.2$ & $(1.1-2.1)$ \\
\hline Sea-run & 10 & $\begin{array}{l}\text { Female 5, } \\
\text { unknown } 5\end{array}$ & $262.3 \pm 97.4$ & $(174.0-435.0)$ & $399.3 \pm 476.3$ & $(65.0-1300.0)$ & $1.6 \pm 0.3$ & $(1.2-2.1)$ \\
\hline $\begin{array}{l}\text { Freshwater- } \\
\text { resident }\end{array}$ & 14 & $\begin{array}{c}\text { Male 6, } \\
\text { female } 7 \\
\text { unknown } 1\end{array}$ & $406.1 \pm 80.7$ & $(283.0-564.0)$ & $929.9 \pm 566.2$ & $(310.0-2552.0)$ & $1.4 \pm 0.2$ & $(1.1-1.6)$ \\
\hline
\end{tabular}

way. The combined supernatants and $30 \mathrm{ml}$ of saturated $\mathrm{NaCl}$ solution were transferred to a separatory funnel. The analytes were extracted twice using $15 \mathrm{ml}$ of ethyl acetate/hexane (3/2) solution. Fifty ml of hexane was mixed with the combined organic layers and the mixture was allowed to stand for $30 \mathrm{~min}$. After removal of the aqueous layer, the organic layer was dried with anhydrous $\mathrm{Na}_{2} \mathrm{SO}_{4}$, concentrated up to trace level using a rotary evaporator, and further concentrated using a nitrogen purge. The analytes were diluted with $3 \mathrm{ml}$ of ethanol, $3 \mathrm{ml}$ of acetic acid-sodium acetate buffer (pH 5.0) and $10 \mathrm{ml}$ of distilled water, ethylated using $1 \mathrm{ml}$ of $5 \% \mathrm{NaBEt}_{4}$ and allowed to stand overnight. The lipids were then saponificated with $5 \mathrm{ml}$ of $1 \mathrm{M} \mathrm{KOH}$-ethanol solution by shaking for $1 \mathrm{~h}$. Forty $\mathrm{ml}$ of distilled water and $10 \mathrm{ml}$ of hexane were added to the solution, and ethylated OTs in the mixed sample solution were extracted to an organic layer by shaking for $10 \mathrm{~min}$. The ethylated OT residue in the aqueous layer was extracted again by shaking for $10 \mathrm{~min}$ with $10 \mathrm{ml}$ of hexane. The combined organic layers were dried with anhydrous $\mathrm{Na}_{2} \mathrm{SO}_{4}$. After being concentrated up to $1 \mathrm{ml}$ using a rotary evaporator and nitrogen gas, the solution was cleaned using a Florisil Sep-Pak column (Waters Associates). The analytes were eluted with $5 \%$ diethyl ether/ hexane, and TeBT- $\mathrm{d}_{36}$ and TePT- $\mathrm{d}_{20}$ were then added as internal standards. The final solution was then concentrated up to $0.5 \mathrm{ml}$.

A Hewlett Packard 6890 series gas chromatograph equipped with a mass spectrometer (5973 N) was used for the analysis of OTs with selected ion monitoring. The separation was carried out in a capillary column coated with $5 \%$ phenyl methyl silicone (J\&W Scientific; $30 \mathrm{~m}$ length $\times 0.25 \mathrm{~mm}$ i.d., $0.25 \mu \mathrm{m}$ film thickness). The column temperature was held at $60^{\circ} \mathrm{C}$ for the first $2 \mathrm{~min}$, then increased to $130^{\circ} \mathrm{C}$ at $20^{\circ} \mathrm{C} \mathrm{min}^{-1}$, to $210^{\circ} \mathrm{C}$ at $10^{\circ} \mathrm{C}$ $\mathrm{min}^{-1}$, to $260^{\circ} \mathrm{C}$ at $5^{\circ} \mathrm{C} \mathrm{min}^{-1}$, and to $300^{\circ} \mathrm{C}$ at $10^{\circ} \mathrm{C}$ $\mathrm{min}^{-1}$. Finally, the column temperature was maintained at $300^{\circ} \mathrm{C}$ for $2 \mathrm{~min}$. The interface temperature, ion source temperature and ion energy were $280^{\circ} \mathrm{C}, 230^{\circ} \mathrm{C}$ and $70 \mathrm{eV}$, respectively. Selected ion monitoring was performed under this program. Splitless injection ( $1 \mu \mathrm{l})$ of the sample was employed. The concentrations of OTs in this study are expressed as $\mathrm{Sn}^{4+}$ based on wet weight of the biological samples.

To examine the quality of the data obtained by the analytical procedure, the soft tissues of the fish were spiked with $0.05 \mu \mathrm{g}$ of BTs and PTs. The recoveries of the BTs and PTs were in the range of 85 to $100 \%$ and 87 to $108 \%$, respectively, and their relative standard deviations (RSD) were in the range of 6.7 to $9.7 \%$ and 9.8 to $12 \%$, respectively. The detection limit for each OT for a signal-to-noise ratio of 3 was $0.5 \mathrm{ng} \mathrm{g}^{-1}$ wet wt of the biological samples.

Otolith preparation and $\mathrm{X}$-ray microprobe analysis. Sagittal otoliths were extracted from each fish, embedded in epoxy resin (Struers, Epofix), and mounted on glass slides. To expose the core along the anteriorposterior direction in the sagittal plane, the otoliths were then ground using a grinding machine that was equipped with a diamond cup-wheel (Struers, Discoplan-TS) and polished further with an OP-S suspension on an automated polishing wheel (Struers, RotoPol-35) that was equipped with a semi-automatic specimen mover (Struers, PdM-Force-20). Finally, they were cleaned using distilled water and ethanol, and dried at $50^{\circ} \mathrm{C}$ in an oven prior to examination.

For electron microprobe analyses, all otoliths were Pt-Pd coated using a high vacuum evaporator. All specimens were used for the 'life-history transect' analysis of the $\mathrm{Sr}$ and $\mathrm{Ca}$ concentrations, which were measured along a line down the longest axis of each otolith from the core to the edge using a wavelength dispersive X-ray electron microprobe (JEOL JXA-8900R) as described by Arai et al. (1997, 2004). Wollastonite (Ca$\left.\mathrm{SiO}_{3}\right)$ and tausonite $\left(\mathrm{SrTiO}_{3}\right)$ were used as standards, and the accelerating voltage and beam current were $15 \mathrm{kV}$ and $1.2 \times 10^{-8} \mathrm{~A}$, respectively. The electron beam was focused on a point measuring $10 \mu \mathrm{m}$ in diameter, with measurements being spaced at $10 \mu \mathrm{m}$ intervals. 
Statistics. Differences between data were analyzed using the Mann-Whitney $U$-test. Differences among data were examined by an analysis of variance (ANOVA), and afterwards Scheffe's multiple range tests for the combination of 2 data. The significance of the correlation coefficient and regression slope were tested by Fisher's Z-transformation and an analysis of covariance (ANCOVA) (Sokal \& Rohlf 1995).

\section{RESULTS}

\section{Life history transects}

Typical life history transects representative of the 2 migratory types of Salmo trutta are shown in Fig. 2. The otolith transects are read from the core to the outer edge; older deposits are closer to the core, while deposits that are more recent in the life history of the fish are farther from the core. The $\mathrm{Sr}$ :Ca ratios measured along a transect from the core to the edge of otoliths of specimens collected from rivers were consistently low (average: $1.4 \pm 0.2 \times 10^{-3}$; range: 1.1 to $1.6 \times$

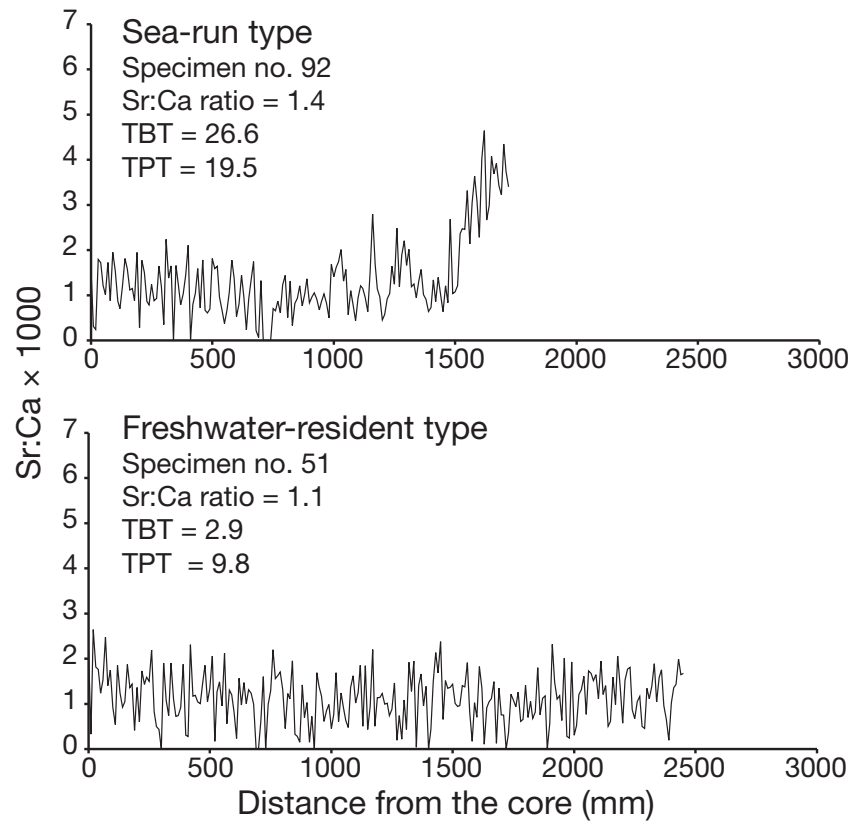

Fig. 2. Salmo trutta. Typical patterns of the otolith $\mathrm{Sr}$ :Ca ratio along line transects from the core $(0 \mu \mathrm{m})$ to the edge in the sagittal plane of the sagittal otoliths of 2 specimens (left). Each specimen was classified into 1 of 2 general migratory categories. Values of the $\mathrm{Sr}: \mathrm{Ca}(\times 1000)$ ratio used to separate each specimen into the general categories sea-run (anadromous) and freshwater-resident (nonanadromous) are given. Specimen identification numbers, and tributyltin and triphenyltin concentrations (ng g ${ }^{-1}$ wet wt) are also given. Variations in migratory pattern in a sea-run individual are also illustrated (right)
$10^{-3}$; e.g. specimen no. 51: Fig. 2), suggesting continuous residence in a freshwater habitat after hatching. In contrast, all individuals collected from the bay showed low $\mathrm{Sr}$ :Ca ratio phases from the core to a point at 650 $2710 \mu \mathrm{m}$ (phase $\mathrm{L}$; average: $1.3 \pm 0.2 \times 10^{-3}$, range: 1.1 to $1.6 \times 10^{-3}$ ). Thereafter, the ratios increased sharply (average: $2.9 \pm 0.7 \times 10^{-3}$, range: 1.6 to $3.7 \times 10^{-3}$ ), and were maintained at the higher levels until the outermost regions (phase $\mathrm{H}_{i}$ e.g. specimen nos. 87, 88, 92: Fig. 2). The fish presumably migrated down and settled in the sea. The mean $\mathrm{Sr}$ :Ca ratio from the core to the edge of the otolith in all fish from the bay was significantly higher than that in fish from the rivers (Mann-Whitney $U$-test, $\mathrm{p}<0.05)$. Thus, we could confirm the fish migratory patterns using otolith $\mathrm{Sr}: \mathrm{Ca}$ ratio analysis, i.e. all fish collected from the rivers were of the freshwater-resident type, and all fish collected from the bay were of the sea-run type.

In addition to these 2 distinctive migratory types of brown trout, a sea-run individual showed a different pattern of migratory history (Fig. 2). Typical sea-run specimens showed higher values out to the otolith edge after the low level in their $\mathrm{Sr}$ :Ca ratio (e.g. speci-
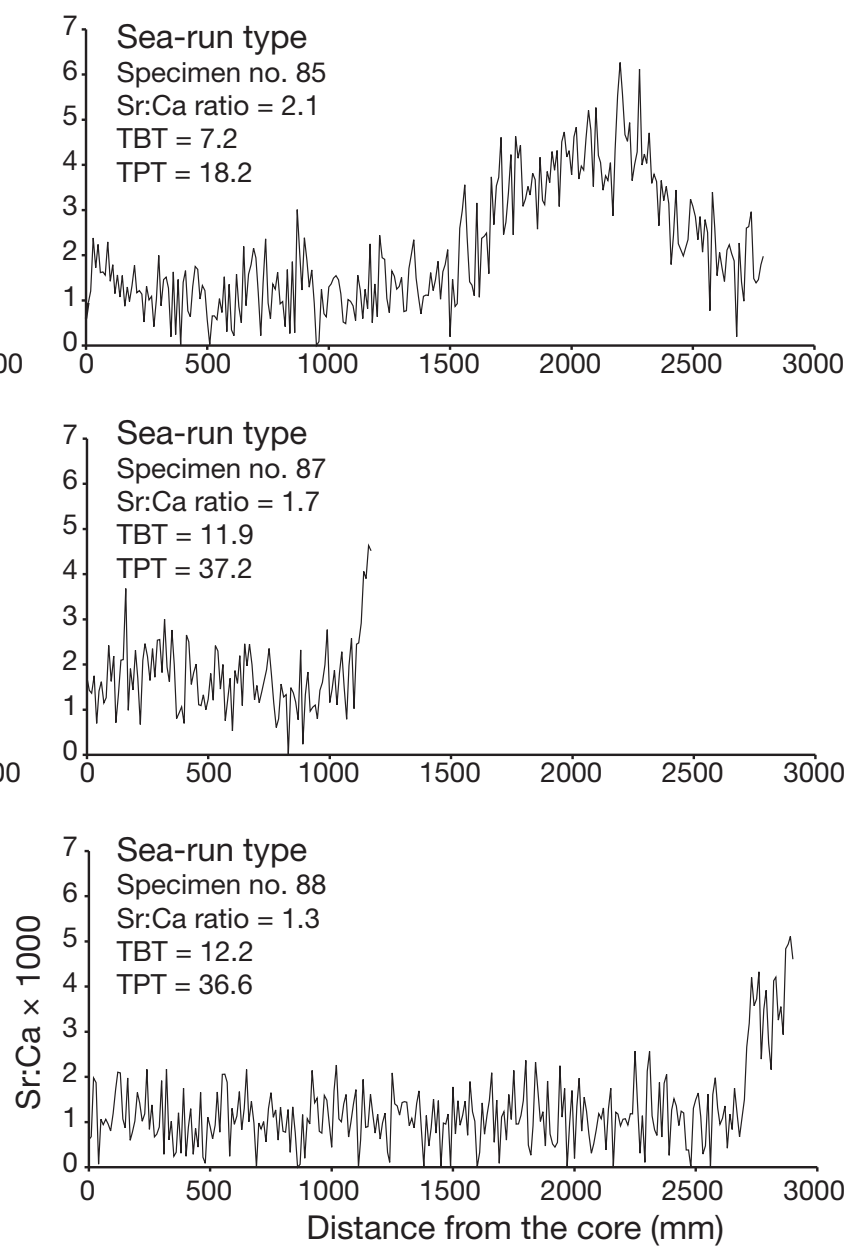
men nos. 87, 88, 92). This change in $\mathrm{Sr}$ :Ca ratio indicates a single movement from one salinity habitat to the next, in which the specimen presumably spent time in a river and moved to the sea where these were collected. However, some specimens (e.g. specimen no. 85 in Fig. 2) showed further low values in the $\mathrm{Sr}: \mathrm{Ca}$ ratio after the high values that followed the initial low levels, indicating downward migration and settling in the sea, followed by a return migration to the river where they were collected.

\section{Relationship between organotin accumulation and biological characteristics}

In both sea-run and freshwaterresident brown trout, no significant relationships were observed between the $\Sigma \mathrm{BTs}(\Sigma \mathrm{BTs}=\mathrm{TBT}+\mathrm{DBT}+\mathrm{MBT})$ levels and FL and BW, and between TBT levels and FL and BW (ANCOVA, p > $0.1-0.5$ ) (Fig. 3). Moreover, no correlations were observed between the $\Sigma$ PTs $(\Sigma \mathrm{PTs}=\mathrm{TPT}+\mathrm{DPT}+\mathrm{MPT})$ levels and FL and BW in both migratory types (ANCOVA, p > $0.05-0.1$ ), although positive and negative relationships were observed between the $\Sigma$ PT levels and BW in the freshwater-resident type, and between TPT levels and FL in the sea-run type, respectively (ANCOVA, p < 0.05) (Fig. 3).

In the freshwater-resident type, the $\Sigma$ BT concentrations in males and females were $15.2 \pm 4.6$ and $16.6 \pm$ $7.6 \mathrm{ng} \mathrm{g}^{-1}$ wet wt, respectively, while the $\Sigma$ PT concentrations were $5.8 \pm 5.8$ and $12.2 \pm 7.5 \mathrm{ng} \mathrm{g}^{-1}$ wet wt (Fig. 4). There were no significant differences in $\Sigma$ BT or $\Sigma$ PT concentrations between the sexes (Mann-Whitney $U$-test, p > $0.05-0.5)$. TBT concentrations in male and female fish were $4.5 \pm 3.2$ and 4.9 $\pm 2.3 \mathrm{ng} \mathrm{g}^{-1}$ wet wt, respectively, while TPT concentrations in male and female fish were $4.4 \pm 4.3$ and $8.3 \pm$ $5.0 \mathrm{ng} \mathrm{g}^{-1}$ wet wt (Fig. 4). No significant differences were also observed in the TBT or TPT concentrations between the sexes (Mann-Whitney $U$-test, $p>0.1$ ). The compositions of BTs and PTs in male fish were also almost identical to those in females (Fig. 4).
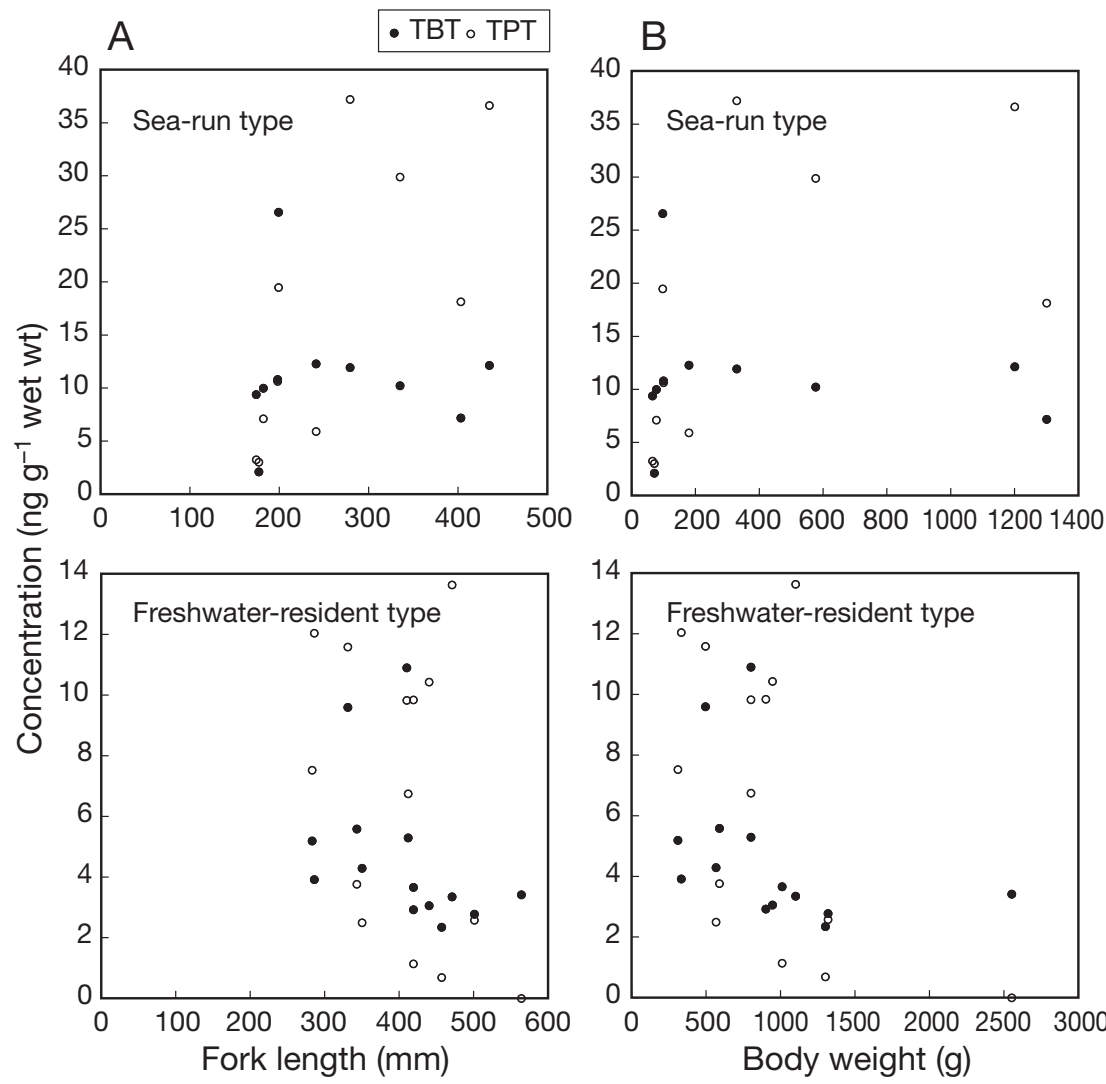

Fig. 3. Salmo trutta. Relationship between tributyltin (TBT) and triphenyltin (TPT) concentrations in the livers and (A) fork length and (B) body weight of (top) sea-run and (bottom) freshwater-resident specimens
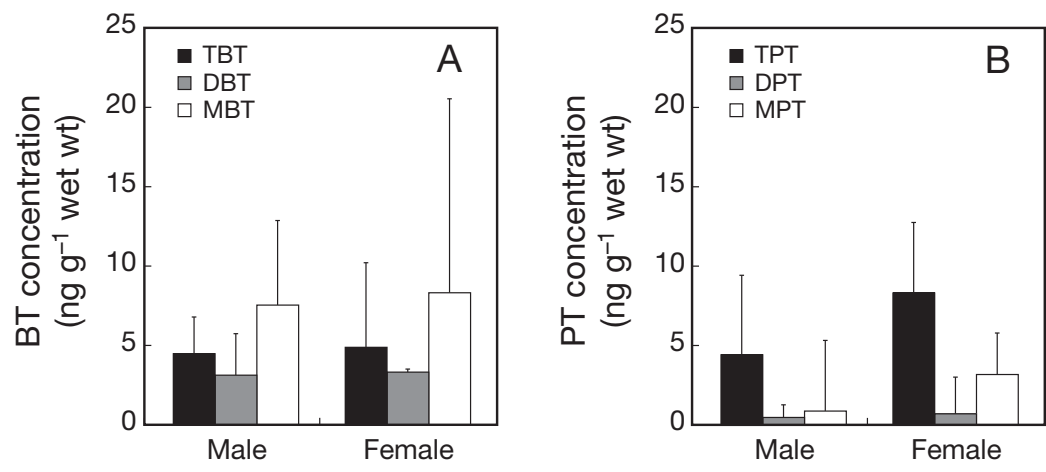

Fig. 4. Salmo trutta. (A) Butyltin (BT) and (B) phenyltin (PT) concentrations in the livers of male and female freshwater-resident specimens. TBT: tributyltin; DBT: dibutyltin; MTB monobutyltin; TPT: triphenyltin; DPT: diphenyltin; MPT: monophenyltin

\section{Difference in organotin accumulation between sea-run and freshwater-resident types}

The respective $\Sigma \mathrm{BT}$ concentrations in sea-run and freshwater-resident brown trout were $33.7 \pm 11.2$ and $17.4 \pm 8.0 \mathrm{ng} \mathrm{g}^{-1}$ wet $\mathrm{wt}$, while the respective TBT values were $11.3 \pm 6.2$ and $4.7 \pm 2.5 \mathrm{ng} \mathrm{g}^{-1}$ wet wt (Fig. 5). 
The $\Sigma \mathrm{BT}$ and TBT values in the sea-run type were significantly higher than in the freshwater-resident type (Mann-Whitney $U$-test, $\mathrm{p}<0.001-0.005)$. The respective $\Sigma \mathrm{PT}$ values in the sea-run and freshwater-resident types were $23.2 \pm 10.2$ and $10.6 \pm 8.6 \mathrm{ng} \mathrm{g}^{-1}$ wet wt, while the respective TPT values were $17.1 \pm 13.4$ and $6.6 \pm 4.7 \mathrm{ng} \mathrm{g}^{-1}$ wet wt (Fig. 5). The $\Sigma$ PT and TPT levels in the sea-run type were significantly higher than in the freshwater-resident type (Mann-Whitney $U$-test, $\mathrm{p}<0.005-0.05$ )

The percentage of TBT in the $\Sigma$ BTs suggests that the breakdown products of TBT, rather than TBT itself, predominate among the $\Sigma$ BTs in both migratory types. The percentage of TBT in the sea-run type was higher than in the freshwater-resident type (Fig. 6). In contrast, TPT generally dominated the $\Sigma$ PTs in both migratory types. The percentage of TPT in the sea-run type was lower than in the freshwater-resident type (Fig. 6).

In the present study, several individual sea-run fish showed TBT and TPT concentrations that were higher than the mean value. The highest concentration of TBT (26.6 $\mathrm{ng} \mathrm{g}^{-1}$ wet $\mathrm{wt}$ ) was detected in specimen no. 92, and this was accompanied by a higher $\mathrm{Sr}: \mathrm{Ca}$ ratio
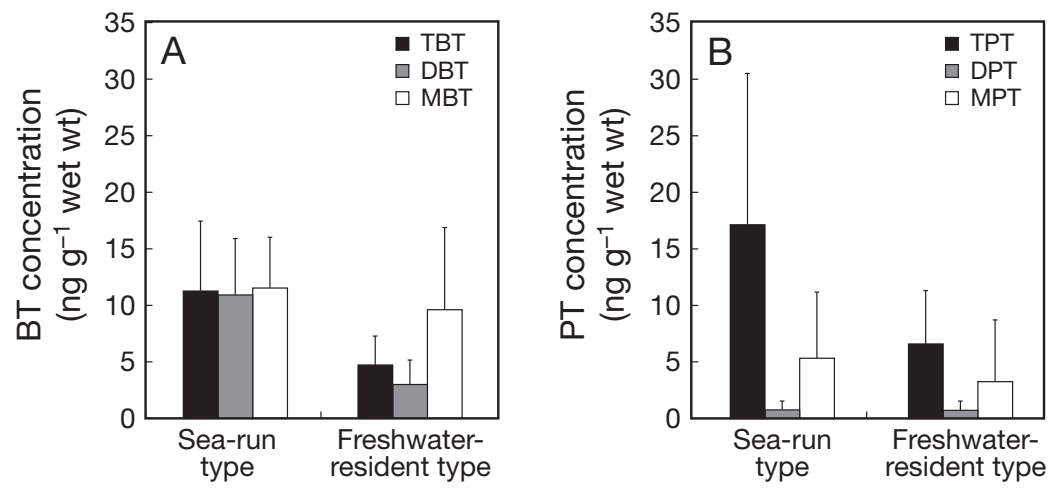

Fig. 5. Salmo trutta. (A) Butyltin and (B) phenyltin concentrations in the livers of sea-run and freshwater-resident specimens. See Fig. 4 for abbreviations
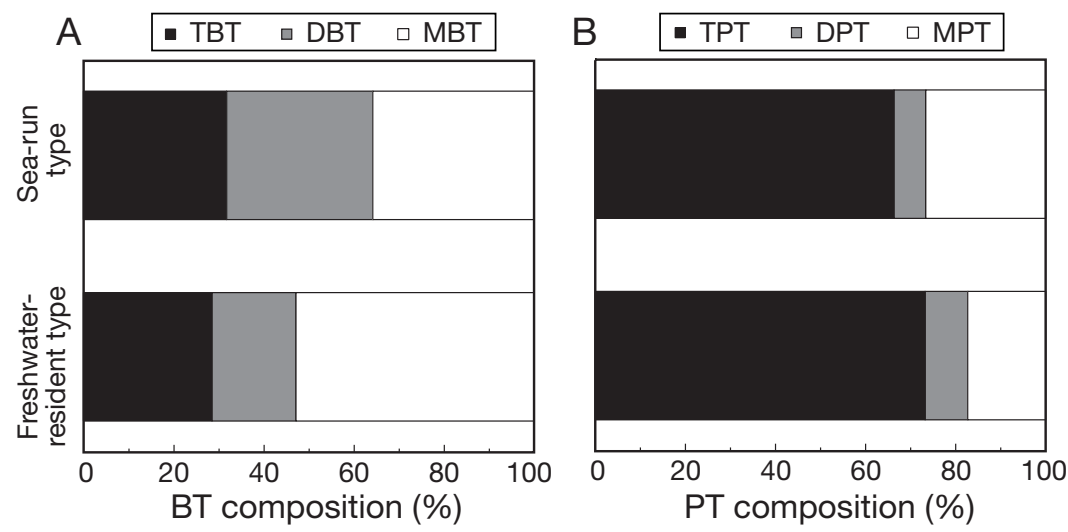

Fig. 6. Salmo trutta. (A) Butyltin and (B) phenyltin compositions in the livers of sea-run and freshwater-resident specimens. See Fig. 4 for abbreviations $\left(3.5 \times 10^{-3}\right)$ after movement to seawater. A higher concentration of TPT (19.5 $\mathrm{ng} \mathrm{g}^{-1}$ wet wt) was also detected in specimen no. 92. In specimen nos. 87 and 88 , we found TBT concentrations of 11.9 and $12.2 \mathrm{ng} \mathrm{g}^{-1}$ wet $\mathrm{wt}$, together with higher concentrations of TPT (37.2 and $36.6 \mathrm{ng} \mathrm{g}^{-1}$ wet $\mathrm{wt}$, respectively). Higher $\mathrm{Sr}: \mathrm{Ca}$ ratios $\left(3.6\right.$ and $\left.3.7 \times 10^{-3}\right)$ after movement to seawater were detected in these individuals.

These results suggest that OT levels in sea-run brown trout were significantly higher than in freshwater-resident ones.

\section{DISCUSSION}

\section{Relationships between organotin accumulation and biological characteristics}

The present study suggests that TBT and TPT accumulation in brown trout did not generally depend on biological characteristics such as growth and sex. No correlation between TBT concentration and fish length has also been reported in the Japanese sea perch Lateolabrax japonicus, the white croaker Pennehia argentatu or the yellowtail Seriola quinqueradiata (Harino et al. 2000). OT residues in fish are not greatly affected by size, but are more likely to reflect the recent history of OT contamination in their environment. In a previous study, TBT concentration was found to be less affected by total length (TL) and age in perch Perca fluviatilis and ruffe Gymnocephalus cernuus, although TPT concentrations increased with both length and age (Stäb et al. 1996). This indicates that TBT is more easily metabolized or eliminated as di- and mono-OTs than TPT. Thus, TPT might accumulate throughout a fish's life history, whereas TBT might show no such accumulation trend. However, this accumulation pattern of TPT was different from that found in the present study. Furthermore, our previous study in the Japanese eel Anguilla japonica (Ohji et al. 2006b) also indicated that both TBT and TPT concentrations in the liver were independent of TL, BW and sex. Therefore, the metabolic capacity to degrade OTs may differ among species. Since studies on the relationship between TPT levels and biometric features have been carried out only at a rudimentary level to date, further study on this topic is necessary. 


\section{Organotin accumulation accompanying migration}

The Sr:Ca ratio along the life history transect in the otolith of Salmo trutta revealed the coexistence of 2 contrasting Sr:Ca ratio patterns, suggesting alternative anadromous (sea-run) and nonanadromous (freshwater-resident) life history styles. It was noteworthy that the TBT and TPT concentrations in the sea-run fish in the present study were significantly higher than in freshwater-resident fish despite both types belonging to the same species. Since TBT and TPT have been used mainly in marine environments, sea-run individuals are expected to experience greater exposure to TBT and TPT during migration to coastal and oceanic waters. Moreover, TBT and TPT residues in sea-run fish indicate continuous inputs of TBT and TPT into the sea despite the ban on their usage. In contrast, since freshwater-resident individuals remain in the freshwater environment throughout their life, they are exposed to less TBT and TPT. Therefore, the risk of TBT and TPT exposure in sea-run fish is higher than in freshwater-resident fish.

In the present study, high concentrations of TBT were detected in several individual sea-run brown trout (e.g. $26.6 \mathrm{ng} \mathrm{g}^{-1}$ wet wt for specimen no. 92) (Fig. 2). Two patterns of migratory history were observed within the sea-run type (Fig. 2). Specimen no. 92 showed a sharp change in the Sr:Ca ratio from low to high levels, indicating movement to the sea after spending a certain amount of time in freshwater. Another sea-run individual (specimen no. 85) showed a change in the $\mathrm{Sr}$ :Ca ratio from low to high levels, and then back to low levels after spending a certain amount of time at high levels, presumably indicating migration from the river down to the sea to grow and settle in the sea habitat, followed by migration back to the river to breed. These results suggest that a constant $\mathrm{Sr}: \mathrm{Ca}$ ratio indicates staying within a small home range, and changes in the $\mathrm{Sr}$ :Ca ratio indicate movement between different habitats. Therefore, even within the same category, there are various levels of risk of OT exposure in brown trout.

The present study found differences in composition between BTs and PTs. TBT and its metabolites, DBT and $\mathrm{MBT}$, were found in approximately equal percentages in both sea-run and freshwater-resident individuals. In contrast, TPT generally dominated over DPT and MPT in both migratory types. We also found similar results in the sea-run masu salmon Oncorhynchus masou and in the Japanese eel Anguilla japonica (Ohji et al. 2006a, b, 2007b, 2009). High DBT and MBT levels among BTs were detected in liver tissue of pike Esox lucius, with TPT concentration also being high (Stäb et al. 1996). A different metabolic capacity to degrade TBT and TPT was found in the European eel Anguilla anguilla and in the rainbow trout $O$. mykiss in a previous in vitro experiment (Fent \& Bucheli 1994). Liver microsomes in eel and rainbow trout were affected by TBT and TPT. TPT strongly inhibited ethoxyresorufin $O$-deethylase (EROD) activity and led to the inactivation of P-450 enzymes more strongly than TBT. These results might be due to the fact that TBT is more easily dealkylated in the liver and excreted via bile than is TPT, since the liver's metabolic capacity to degrade TBT is higher than its capacity to degrade TPT in Salmo trutta. This implies that TPT is very stable in aquatic ecosystems.

\section{The risk of organotin compounds in Salmo trutta}

The present study clearly demonstrates that the diadromous fish Salmo trutta is at variable risk of exposure to TBT and TPT due to intraspecific variation in migratory patterns, while that OT accumulation does not depend on body size or sex. Therefore, a comparison of the contamination levels of OTs in brown trout from different regions should be conducted with specific reference to migratory histories. Since adverse effects of TBT and TPT (e.g. histopathological alteration in fishes even at ambient water levels) have been reported (Fent 1992, Fent \& Meier 1992, 1994), these substances might also adversely influence $S$. trutta. The higher ecological risk posed by TBT and TPT to sea-run over freshwater-resident individuals indicates that the former might be more conspicuously affected by these substances. However, TBT and TPT might not only affect the sea-run type, but also the freshwaterresident type. After sea-run brown trout complete their oceanic migration, they return to their natal river and participate in reproductive activities with the freshwater-resident type. It has been reported that TBT and TPT exposure detrimentally affects reproduction in the African catfish Clarias gariepinus, the herring Clupea harengus and the European minnow Phoxinus phoxinus (Fent 1992, Fent \& Meier 1992, 1994, Rurangwa et al. 2002, Grzyb et al. 2003). Moreover, the reproductive toxicity of triorganotin has also been reported to induce population disturbance. Masculinization (imposex) induced by TBT and TPT exposure in female gastropods has been found to lead to reproductive failure and subsequent population decline (Bryan et al. 1986, Gibbs \& Bryan 1986, Bettin et al. 1996, Matthiessen \& Gibbs 1998). Therefore, TBT and TPT exposure might also affect the reproductive systems of sea-run brown trout.

Furthermore, it has been reported that some salmonid fishes, which show an anadromous life history and are semelparous, transport upstream not only nutrients but also many carcasses (Ewald et al. 1998, Naiman et al. 2002, Krümmel et al. 2003). Krümmel et al. (2003) 
reported the biotransport in which PCB concentrations in river sediment where salmon migrated for spawning were higher than in river sediment where spawning migration did not occur. Thus, OTs might also be transported upstream and deposited into river sediments via salmonids such as sea-run brown trout. Therefore, anadromous fish, such as sea-run brown trout, might have the potential risk to transport OTs from the ocean to river sediments, secondarily acting as vectors and exposing freshwater-resident fish to the risk of OT contamination, despite OTs having been mainly used in the ocean. Thus, the risks involved in the exposure of the sea-run type to TBT and TPT might in turn influence freshwater-resident individuals, and lead to the disturbance of the $S$. trutta population.

Acknowledgements. We thank Dr. K. Miyashita for assistance in collecting the specimens. The study was partially supported by Grants-in-Aid from the Ministry of Education, Culture, Sports, Science and Technology, Japan (Nos. 18780141, 19681005 and 20688008).

\section{LITERATURE CITED}

Arai T, Tsukamoto K (1998) Application of otolith Sr:Ca ratios to estimate the migratory history of masu salmon, Oncorhynchus masou. Ichthyol Res 45:309-313

Arai T, Otake T, Tsukamoto K (1997) Drastic changes in otolith microstructure and microchemistry accompanying the onset of metamorphosis in the Japanese eel, Anguilla japonica. Mar Ecol Prog Ser 161:17-22

Arai T, Kotake A, Aoyama T, Hayano H, Miyazaki N (2002) Identifying sea-run brown trout, Salmo trutta, using Sr:Ca ratios of otolith. Ichthyol Res 49:0380-0383

Arai T, Kotake A, Lockman PM, Miller MJ, Tsukamoto K (2004) Evidence of different habitat use by New Zealand freshwater eels Anguilla australis and A. dieffenbachii, as revealed by otolith microchemistry. Mar Ecol Prog Ser 266:213-225

Bettin C, Oehlmann J, Stroben E (1996) TBT-induced imposex in marine neogastropods is mediated by an increasing androgen level. Helgol Meeresunters 50:299-317

Blunden SJ, Evans CJ (1989) Organotin compounds. In: Hutzinger $\mathrm{O}$ (ed) The handbook of environmental chemistry, Vol 3, Part E - Anthropogenic compounds. SpringerVerlag, Berlin, p 1-44

Bosselmann K (1996) Environmental law and tributyltin in the environment. In: de Mora SJ (ed) Tributyltin: case study of an environmental contaminant. Cambridge University Press, Cambridge, p 237-263

Bryan GW, Gibbs PE, Hummerstone LG, Burt GR (1986) The decline of the gastropod Nucella lapillus around southwest England: evidence for the effect of tributyltin from antifouling paints. J Mar Biol Assoc UK 66:611-640

Campana SE (1999) Chemistry and composition of fish otoliths: pathways, mechanisms and applications. Mar Ecol Prog Ser 188:263-297

Elliott JM (1994) Quantitative ecology and the brown trout. Oxford University Press, New York

Ewald G, Larsson P, Linge H, Okla L, Szarzi N (1998) Biotransport of organic pollutants to an inland Alaska lake by migrating sockeye salmon (Oncorhynchus nerka). Arctic
$51: 40-47$

Fent K (1992) Embryotoxic effects of tributyltin on the minnow Phoxinus phoxinus. Environ Pollut 76:187-194

Fent K, Bucheli TD (1994) Inhibition of hepatic microsomal monooxygenase system by organotins in vitro in freshwater fish. Aquat Toxicol 28:107-126

Fent K, Meier W (1992) Tributyltin-induced effects on early life stages of minnows Phoxinus phoxinus. Arch Environ Contam Toxicol 22:428-438

Fent K, Meier W (1994) Effects of triphenyltin on fish early life stages. Arch Environ Contam Toxicol 27:224-231

Gibbs PE, Bryan GW (1986) Reproductive failure in populations of the dog-whelk, Nucella lapillus, caused by imposex induced by tributyltin from antifouling paints. J Mar Biol Assoc UK 66:767-777

Grzyb K, Rychlowski M, Biegniewska A, Skorkowski EF (2003) Quantitative determination of creatine kinase release from herring (Clupea harengus) spermatozoa induced by tributyltin. Comp Biochem Physiol 134C:207-213

> Harino H, Fukushima M, Kawai S (2000) Accumulation of butyltin and phenyltin compounds in various fish species. Arch Environ Contam Toxicol 39:13-19

> Harino H, O'Hara SCM, Burt GR, Pope ND, Chesman BS, Langston WJ (2002) Butyltin and phenyltin compounds in eels (Anguilla anguilla). J Mar Biol Assoc UK 82:893-901

Kalish JM (1990) Use of otolith microchemistry to distinguish the progeny of sympatric anadromous and non-anadromous salmonids. Fish Bull 88:657-666

Krümmel EM, MacDonald RW, Kimpe LE, Gregory-Eaves I, Demers MJ, Smol JP, Finney B, Blais JM (2003) Delivery of pollutants by spawning salmon. Nature 425:255-256

> Matthiessen P, Gibbs PE (1998) Critical appraisal of the evidence for tributyltin-mediated endocrine disruption in molluscs. Environ Toxicol Chem 17:37-43

Naiman RJ, Bilby RE, Schindler DE, Helfield JM (2002) Pacific salmon, nutrients, and the dynamics of freshwater and riparian ecosystems. Ecosystems (NY, Print) 5:399-417

Ohji M, Arai T, Miyazaki N (2002a) Effects of tributyltin exposure in the embryonic stage on sex ratio and survival rate in the caprellid amphipod Caprella danilevskii. Mar Ecol Prog Ser 235:171-176

Ohji M, Takeuchi I, Takahashi S, Tanabe S, Miyazaki N (2002b) Differences in the acute toxicities of tributyltin between the Caprellidea and the Gammaridea (Crustacea: Amphipoda). Mar Pollut Bull 44:16-24

Ohji M, Arai T, Miyazaki N (2003a) Chronic effects of tributyltin on the caprellid amphipod Caprella danilevskii. Mar Pollut Bull 46:1263-1272

Ohji M, Arai T, Miyazaki N (2003b) Timing of sex disturbance caused by tributyltin exposure during the embryonic stage in the caprellid amphipod, Caprella danilevskii. J Mar Biol Assoc UK 83:943-944

Ohji M, Arai T, Miyazaki N (2006a) Differences of tributyltin accumulation on the masu salmon Oncorhynchus masou between sea-run and freshwater-resident types. J Fish Biol 68:931-939

> Ohji M, Harino H, Arai T (2006b) Differences in organotin accumulation among ecological migratory types of the Japanese eel Anguilla japonica. Estuar Coast Shelf Sci 69: 270-290

Ohji M, Arai T, Miyazaki N (2006c) Transfer of tributyltin from parental female to offspring in the viviparous surfperch Ditrema temmincki. Mar Ecol Prog Ser 307:307-310

> Ohji M, Arai T, Midorikawa S, Harino H, Masuda R, Miyazaki N (2007a) Distribution and fate of organotin compounds in Japanese coastal waters. Water Air Soil Pollut 178: 255-265 
Ohji M, Arai T, Miyazaki N (2007b) Comparison of organotin accumulation in the masu salmon Oncorhynchus masou accompanying migratory histories. Estuar Coast Shelf Sci 72:721-731

Ohji M, Harino H, Arai T (2009) Variation in organotin accumulation in relation to the life history in the Japanese eel Anguilla japonica. Estuar Coast Shelf Sci 84:28-36

Rurangwa E, Biegniewska A, Slominska E, Skorkowski EF, Ollevier F (2002) Effect of tributyltin on adenylate content and enzyme activities of teleost sperm: a biochemical approach to study the mechanisms of toxicant reduced spermatozoa motility. Comp Biochem Physiol 131C: 335-344

Secor DH, Henderson-Arzapalo A, Piccoli PM (1995) Can otolith microchemistry chart patterns of migration and habitat utilization in anadromous fishes? J Exp Mar Biol Ecol 192:15-33

Snoeij NJ, Penniks AH, Seinen W (1987) Biological activity of organotin compounds - an overview. Environ Res 44: 335-353

Sokal RR, Rohlf FJ (1995) Biometry, 3rd edn. WH Freeman

Editorial responsibility: Matthias Seaman,

Oldendorf/Luhe, Germany and Company, New York

Stäb JA, Traas TP, Stroomberg G, van Kesteren J and others (1996) Determination of organotin compounds in the foodweb of a shallow freshwater lake in the Netherlands. Arch Environ Contam Toxicol 31:319-328

Tsukamoto K, Arai T (2001) Facultative catadromy of the eel, Anguilla japonica, between freshwater and seawater habitats. Mar Ecol Prog Ser 220:265-276

Ward GS, Gramm GC, Parrish PR, Trachman H, Slesinger A (1981) Bioaccumulation and chronic toxicity of bistributyltin oxide TBTO: tests with a saltwater fish. In: Branson DR, Dickson KL (eds) Aquatic toxicology and hazard assessment. Fourth Conference, American Society for Testing and Materials, Philadelphia, PA, ASTM STP 737, p 183-200

Watson R (1999) Salmon, trout and charr of the world. Swan Hill Press, Shrewsbury

Wester PW, Canton JH (1987) Histopathological study of Poecilia reticulata (guppy) after long-term exposure to bis(tri-n-butyltin) oxide (TBTO) and di-n-butyltin dichloride (DBTC). Aquat Toxicol 10:143-165

Submitted: May 15, 2009; Accepted: September 1, 2009

Proofs received from author(s): December 25, 2009 